\title{
The Influence of Spiritual Intelligence on the Organizational Commitments of Board Executive Santri (BES) Of PPJA
}

\author{
D Wulandari ${ }^{1}$, M Priantini $^{2}$ \\ ${ }^{1}$ Islamic Building School of Jagad Alimussirry Surabaya, Indonesia \\ ${ }^{2}$ Science Department, Universitas Negeri Surabaya, Indonesia \\ Email: desiwulan770@gmail.com
}

\begin{abstract}
This study aims to determine the level of spiritual intelligence, the level of organizational commitment and to determine whether there is influence of spiritual intelligence on organizational commitment to the management of the Islamic Boarding School Boarding School BES Alimussirry. The research data collection method is using questionnaire techniques.Using the SPSS 23 system and the research t-test technique, the results showed that the level of spiritual intelligence of the BES PPJA management resulted in $42.30 \%$ in the high category, $57.70 \%$ in the moderate category and $0 \%$ in the low category. The percentage for all member respondents is $80.30 \%$, so the management's spiritual intelligence is included in the medium category. While the level of BES PPJA Management Organizational Commitment resulted in 50\% in the high category, $50 \%$ in the medium category and $0 \%$ in the low category category. The percentage for all respondents is $49.73 \%$, so the organizational commitment of the PPJA BES is in the moderate category. so there is an influence or relationship between spiritual intelligence on organizational commitment BES PPJA with the percentage influence of spiritual intelligence of 5\% and the remaining $95 \%$ due to other factors not examined by researchers.
\end{abstract}

Keywords: spiritual intelligence, organizational commitment, and boarding school management.

\section{INTRODUCTION}

The success of an organization is greatly influenced by the performance of its members. Performance is a work achievement, which is a comparison between work results and set work standards. Each organization will strive to improve the performance of its members, to achieve the stated goals, based on the results of work meetings that have been conducted. Member contributions to the organization will be important, if done with effective actions and behaving correctly. To achieve the goals of the organization, a high level of loyalty is required from each member. Loyalty in an individual or member in an organization can be referred to as a form of commitment.

The organization in the Jagad 'Alimussirry Student Boarding School is the BES (Santri
Executive Board) Organization. The BES (Santri Executive Board) organization as a forum to prepare cadres who will become fighters and fight in the pesantren community by continuing to hold the culture in the surrounding environment, as well as to strengthen or strengthen the spiritual nuances of the pesantren community and religious stability that will form social piety. In this spiritual nuance, spiritual intelligence is needed to carry it out.

According to the results of an interview with a board of directors of the Santri Executive Board, he said: "Actually I was not interested in the organization as well as BES, but when Abah Djoko (director of the islamic boarding school) said that the BES was his right hand, everything the BES did was 
mandated by after all, from there I began to be interested and excited about joining BES as my reason for serving my people. Because there is a special interest when serving the goddess. Because abah is one of the role models of the clerics, and he is lillahita'ala more concerned with the afterlife than worldly affairs that not everyone can be like that, besides that he also has a strong stance and always has 10 steps ahead ". regarding this explanation it is clear that there is a special attraction for someone to develop themselves through an organization in a pesantren.

Therefore researchers are interested in raising the title "The Influence of Spiritual Intelligence on Organizational Commitment of BES (Santri Executive Section) of Islamic Boarding School Jagad A'limussirry Surabaya

\section{METHOD}

The research design used uses a quantitative research approach, using the $\mathrm{T}$ Test to know the relationship between the two variables.

\section{RESULT AND DISCUSSION}

\section{A. Data Description}

\section{Free Variable Description (X) Spiritual Intelligence}

Data about spiritual intelligence is obtained from the results of questionnaires that have been distributed by researchers to members of the PPJA Santri Executive Board in Surabaya. The total score of the results of the spiritual intelligence questionnaire is in Table $\mathrm{I}$ as follows:

Table. I Frequency Distribution of Spiritual Intelligence

\begin{tabular}{cccc}
\hline No & Categories & Total & Persent (\%) \\
\hline 1 & High & 11 & 42.30 \\
\hline 2 & Medium & 15 & 57.70 \\
\hline 3 & Low & 0 & 0 \\
\hline
\end{tabular}

The results of frequency distribution data about the level of spiritual intelligence showed the percentage of samples taken resulted in
$42.30 \%$ in the high category, $57.70 \%$ in the medium category and $0 \%$ in the low category. The average score for all BES JA member respondents is 80.30 , so the management's spiritual intelligence is included in the medium category.

\section{Description of Bound Variables Organizational Commitments.}

Table. II Frequency Distribution Organizational Commitments

\begin{tabular}{cccc}
\hline No & Categories & Total & Persent (\%) \\
\hline 1 & High & 13 & 50 \\
\hline 2 & Medium & 13 & 50 \\
\hline 3 & Low & 0 & 0 \\
\hline
\end{tabular}

The results of frequency distribution data about the level of organizational commitment show a percentage of the samples taken resulting in 50\% in the high category, $50 \%$ in the high category and $0 \%$ in the low category category. The average score for all respondents is 49.73 , so the organizational commitment of the PPJA BES is in the moderate category.

\section{B. Test Instruments}

\section{Test Validity}

Based on the validity table using SPSS 23, items from the spiritual intelligence scale and organizational commitment were tested and obtained outputs which were then compared with $r$ tables sought at significance 0.05 and the number of data $\mathrm{N}=26$, then $r$ table was 0.398 (table $\mathrm{r}$ product moment). Can be said to be valid if $r$ count $>$ than $r$ table, so said invalid if $r$ count $<r$ table. From the table, 4 items were declared invalid and 22 items were declared valid. While the results of the validity test for the dependent variable (Y) organizational commitment found in those obtained resulted in a valid category.

\section{Test Reliability}

From the results of the reliability test on the research instrument obtained in Table III as follows: 
Table. III Reliability of Spiritual Intelligence items

\begin{tabular}{cc}
\hline Cronbach's Alpha & N of Items \\
\hline, 846 & 25 \\
\hline
\end{tabular}

Based on the table above obtained Alpha value $=0.846>\mathrm{r}$ table $=0.389$ means that items from spiritual intelligence variables are said to be reliable or reliable as a data collection tool in research. While the reliability of organizational commitment can be seen in table Table IV.

Table. IV Item Organizational Commitment Reliability

\begin{tabular}{cc}
\hline Cronbach's Alpha & N of Items \\
\hline, 874 & 15 \\
\hline
\end{tabular}

Alpha conclusion $=0.874>\mathrm{r}$ table $=0.389$ means that items from organizational commitment variables are said to be reliable or reliable as data collection tools in research.

\section{Test of Basic Assumptions}

\section{Normality Test}

On the results of the normality test above obtained a significance value of the variable (X) spiritual intelligence that is 0.269 and variable $(\mathrm{Y})$ organizational commitment is 0.269 . Both variables are said to be normally distributed if the significance value is $>0.05$ or $5 \%$. Conversely it is said to be abnormally distributed if the significance value is $<0.05$ or $5 \%$. From the results above, it can be seen that spiritual intelligence and organizational commitment are $0.269>0.05$. Thus data from both variables are normally distributed.

The results of frequency distribution data about the level of organizational commitment show a percentage of the samples taken resulting in 50\% in the high category, $50 \%$ in the high category and $0 \%$ in the low category category. The average score for all respondents is 49.73 , so the organizational commitment of the PPJA BES is in the moderate category.

\section{Test for correlation ( $t$ test)}

From the calculation obtained that $\mathrm{t}$ count 2.901> t table 2.069 and it can be seen that the significance value of the effect of $\mathrm{X}$ on $\mathrm{Y}$ is $0.008<0.05$. So that it can be seen that $\mathrm{Hi}$ is accepted and $\mathrm{HO}$ is rejected which means there is an influence between spiritual intelligence and BES organizational commitment. with a determinant percentage of $5 \%$.

\section{E. Effect of Spiritual Intelligence on Organizational Commitment to BES PPJA administrators}

Based on the t-test conducted by the researcher, it was found that there was an influence between spiritual intelligence on BES PJJA organizational commitment. One of the related factors is the daily place of the santri and santri who attend the BES in the shade of the pesantren so that their daily lives are always accompanied by spiritual activities that will train the heart and soul to continue to involve God in everything including commitment in a organization.

In the questionnaire given by a number of respondents from the BES members, they expressed their agreement when given a statement in the form of "I involve God when I get a problem or a problem". The problem referred to here is often felt by a number of BES member respondents in achieving a certain activity or in uniting the sense of family in the pesantren. The statement can be analyzed that the spiritual intelligence possessed by a number of respondents of BES members is very influential on organizational commitment. In this study the percentage relationship between spiritual intelligence and organizational commitment in a small range is 5\% and there are many other factors that influence organizational commitment such as job satisfaction and work ethic. The percentage that is quite low is one of them because researchers only sample half of the total BES PPJA members.

\section{CONCLUSION}

The level of spiritual intelligence of the board of students of the Islamic Boarding 
School Executive Board of Student Islamic Boarding School Alimussirry (BES PPJA) resulted in $42.30 \%$ in the high category, $57.70 \%$ in the medium category and $0 \%$ in the low category. The percentage for all member respondents is $80.30 \%$, so the management's spiritual intelligence is included in the medium category. Level of Organizational Commitment of management of the PPJA Santri Executive Board produces $50 \%$ in the high category, $50 \%$ in the medium category and $0 \%$ in the low category category. The percentage for all respondents is $49.73 \%$, so the organizational commitment of the PPJA BES is in the moderate category.There is an influence or relationship between spiritual intelligence on organizational commitment BES PPJA with the percentage influence of spiritual intelligence of $5 \%$ and the remaining
95\% due to other factors not examined by researchers.

\section{REFERENCES}

[1] Noor Fitriyah, "Pengaruh Kecerdasan Spiritual Terhadap Motivasi Kerja Guru SD Islam Al-Azhar 25 Semarang”, Semarang: Skripsi Tidak Diterbitkan.

[2] Sugiyono, "Metode Penelitian Kuantitatif Kualitatif dan R\&D", Bandung: CV Alfabeta, 2011.

[3] T. A. Rohman, "Pengaruh Kecerdasan Spiritual terhadap Komitmen Organisasi pada pengurus PC IPNU IPPNU Tulungagung", IAIN Tulung Agung, 2016.

[4] D. Zohar, et al. "SQ: Kecerdasan Spiritual", Bandung: Mizan, 2007.

[5] D. Zohar, and I. Marshal, "SQ Spiritual Intelegence, the Ultimate Inteligence", London: Blomsbury, 2000. 